\title{
Salivary Proteins: Protective and Diagnostic Value in Cariology?
}

\author{
A. van Nieuw Amerongen J.G.M. Bolscher E.C.I. Veerman \\ Department of Oral Biochemistry, Academic Centre for Dentistry Amsterdam, Amsterdam, The Netherlands
}

\section{Key Words}

Agglutinin - Antimicrobial peptides · Cathelicidin • Histatins · Lactoferrin · Mucins · Saliva · Salivary proteins

\begin{abstract}
Saliva is essential for a lifelong conservation of the dentition. Various functions of saliva are implicated in the maintenance of oral health and the protection of our teeth: (i) The tooth surface is continuously protected against wear by a film of salivary mucins and proline-rich glycoprotein. (ii) The early pellicle proteins, proline-rich proteins and statherin, promote remineralization of the enamel by attracting calcium ions. (iii) Demineralization is retarded by the pellicle proteins, in concert with calcium and phosphate ions in saliva and in the plaque fluid. (iv) Several salivary (glyco)proteins prevent the adherence of oral microorganisms to the enamel pellicle and inhibit their growth. (v) The salivary bicarbonate/carbonate buffer system is responsible for rapid neutralization of acids. An overview is presented on the major antimicrobial systems in human saliva. Not only the well-known major salivary glycoproteins, including mucins, proline-rich glycoprotein and immunoglobulins, but also a number of minor salivary (glyco)proteins, including agglutinin, lactoferrin, cystatins and lysozyme,
\end{abstract}

\section{KARGER}

Fax +41613061234

E-Mail karger@karger.ch

www.karger.com
(C) 2004 S. Karger AG, Basel

0008-6568/04/0383-0247\$21.00/0

Accessible online at: www. karger.com/cre are involved in the first line of defense in the oral cavity. Besides, small cationic antimicrobial peptides, e.g. defensins, cathelicidin and the histatins, have come into focus. These are potentially suited as templates for the design of a new generation of antibiotics, since they kill a broad spectrum of microorganisms, while hardly evoking resistance, in contrast to the classical antibiotics.

Copyright $@ 2004$ S. Karger AG, Basel

Saliva contains a large number of proteins that participate in the protection of the oral tissues, for instance lysozyme, lactoferrin, lactoperoxidase, immunoglobulins, agglutinin and mucins [e.g. Nieuw Amerongen and Veerman, 2002]. In addition, several peptides with bacteriakilling activity have been identified. These include histatins, defensins and the only human cathelicidin, LL-37 (table 1). Because all these proteins and peptides have a broad spectrum of antimicrobial activity there seems to be a considerable overlap in functionality. This may account for the observation that susceptibility to oral diseases can apparently not be related to the concentration of a single component [Rudney et al., 1999]. The exact reason for this 'redundancy' is not really understood but different features may play a role.

The oral cavity is the home of numerous different microorganisms, of which many still await identification

Dr. A. van Nieuw Amerongen

Vrije Universiteit, Department of Oral Biochemistry

Van der Boechorststraat 7, NL-1081 BT Amsterdam (The Netherlands)

Tel + 31204448675, Fax + 31204448685

E-Mail a.van_nieuw_amerongen.obc.acta@med.vu.nl 
Table 1. Antimicrobial proteins in glandular salivas

\begin{tabular}{llc}
\hline Salivary (glyco)protein & Tissue of origin & Relative $\%$ \\
\hline MUC5B (mucin MG1) & all mucous salivary glands & $5-20$ \\
MUC7 (mucin MG2) & all mucous salivary glands & $5-20$ \\
Immunoglobulins & B lymphocytes: in all salivary glands & $5-15$ \\
Proline-rich glycoprotein & parotid & $1-10$ \\
Cystatins & submandibular > sublingual & 10 \\
Histatins & parotid and submandibular & 5 \\
EP-GP (= GCDFP15, SABP, PIP) & submandibular, sublingual & $1-2$ \\
Agglutinin (= DMBT1, gp340) & parotid > submandibular > sublingual & $1-2$ \\
Lysozyme & sublingual > submandibular, parotid & $1-2$ \\
Lactoferrin & all salivary glands: mucous > serous & $1-2$ \\
Lactoperoxidase & parotid > submandibular & $<1$ \\
Cathelicidin (hCAP18, LL37) & salivary glands, neutrophils & $<1$ \\
Defensins & salivary glands, epithelial cells, neutrophils & $<1$ \\
\hline
\end{tabular}

and characterization. In addition, an unknown number of microorganisms are temporary guests that are transiently present. To cope with such a wide variety of potential invaders, the oral defense should be equipped with a diverse armament to prevent uncontrolled colonization by microorganisms. In this context it has to be noted that the conditions in the oral cavity for some defense systems are suboptimal. For instance, the microbicidal activity of cationic antimicrobial peptides like defensins, histatins and LL37 is known to be sensitive to the ionic environment as evidenced by a reduction in the presence of elevated salt concentrations or low concentrations of divalent cations.

Each type of salivary gland secretes a characteristic spectrum of proteins. The complete arsenal of antimicrobial proteins present in whole saliva is thus the sum of contributions from different glands. As a consequence, the concentration of a single antimicrobial protein will vary over the day in accordance with the activity of its glandular source.

Functional overlap in defensive systems means that no single component is necessary for the overall antimicrobial capacity of the salivary defense system.

The salivary armory contains defensive components/ systems protecting specifically the dentition. Examples of such 'tooth-specific' systems are the carbonate/bicarbonate buffer system (for rapid neutralization of acids) and specific proteins that form a protective coating on the enamel surface, which serves as a barrier to prevent free diffusion of acid. In addition, generic protective systems are present, comprising antimicrobial proteins and peptides, that afford protection against microbial infections and are found in other protective secretions as well. With the exception of the immunoglobulins, antimicrobial components in saliva are not focused on elimination of specific (cariogenic) species, such as Streptococcus mutans (table 2). Rather they prevent massive overgrowth of microorganisms, and govern the establishment and maintenance of a stable ecosystem in which harmless species outnumber potentially dangerous species, thus forming a protection in its own right. In this paper different aspects of the antimicrobial action of a number of salivary protective systems will be discussed.

\section{Protective Properties of the Major Salivary Proteins}

The most important antimicrobial proteins in saliva, and their glandular source, are summarized in table 1.

The salivary immunoglobulins belong primarily $(>85 \%)$ to the IgA subclass and to a lesser extent to the IgG subclass. Together they make up about $5-15 \%$ of total salivary proteins. Salivary IgA is synthesized by B lymphocytes located in the vicinity of secretory epithelia. After secretion in the interstitial fluid, it is taken up by acinar and ductal cells of the salivary gland and subsequently secreted into saliva. IgG in saliva mainly derives from crevicular fluid leaked into the oral cavity. Because of its highly specific binding characteristics, a single immunoglobulin idiotype binds and agglutinates just one or at best a few cross-reactive microbial species. However, the entire population of salivary immunoglobulins binds the majority of microorganisms present in saliva, thus presenting a broad-spectrum defense system. In contrast to immunoglobulins in serum, IgA in saliva does not function as an opsonizing agent, since under normal condi- 
Table 2. Salivary proteins: protective properties

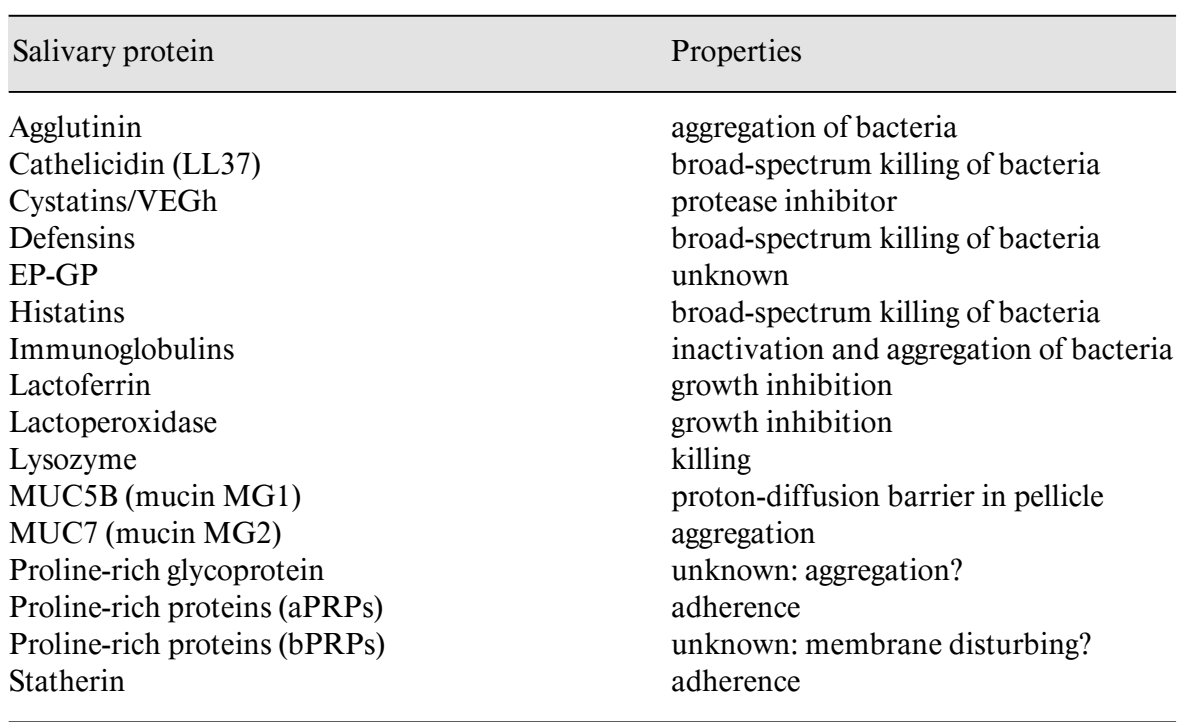

tions no cytotoxic T cells are present in saliva. Also components of the complement system, which in serum cause direct killing of bacteria, are absent in saliva. Thus, the main functions of salivary immunoglobulins tentatively will be inhibition of bacterial adherence and colonization, e.g. by blocking surface structures involved in binding.

Mucins constitute another important class of salivary glycoproteins. In unstimulated whole saliva they are the major components, making up $20-30 \%$ of the total protein. Two types of genetically different salivary mucins can be distinguished [Levine et al., 1987; Loomis et al., 1987]: MG1, high-molecular-weight mucin ( $M_{\mathrm{r}} 10-30$ MDa), encoded by the $M U C 5 B$ gene, now designated MUC5B [Thornton et al., 1999], and the low-molecularweight MG2 $\left(M_{\mathrm{r}} \sim 130 \mathrm{kDa}\right)$, the translation product of the MUC7 gene, now designated MUC7 [Bobek et al., 1993]. Characteristic of mucins is the abundance of carbohydrate side chains which are covalently attached to the polypeptide backbones, forcing the molecule into an extended conformation. On a weight basis, the carbohydrates comprise $60 \%$ (for MUC7) to $80 \%$ (for MUC5B) of the molecule. The large dimensions and elongated form of MUC5B, in combination with the presence of a hydrophilic sugar coat, are responsible for the characteristic viscoelastic character of MUC5B-containing solutions [van der Reijden et al., 1993]. MUC5B is synthesized exclusively in mucous acinar cells of all (sero)mucous salivary glands [Nieuw Amerongen et al., 1995; Veerman et al., 2003]. MUC5B is a constituent of the protein layers that form on dental enamel after prolonged incubation with saliva, and is indispensable for the proton-barrier func- tion of these so-called pellicles [Nieuw Amerongen et al., 1987]. Because of its hydrophilic properties, MUC5Bcontaining pellicles lubricate the dental surfaces, protecting them against mechanical wear. Despite its highly diverse population of oligosaccharides, which are potential receptors for bacterial adhesins, MUC5B binds to relatively few oral microorganisms, including Haemophilus parainfluenzae [Veerman et al., 1995] and Helicobacter pylori [Veerman et al., 1997a]. The low-molecular-weight mucin MUC7 differs from MUC5B in structure, localization and function. MUC7 is a single monomeric protein, decorated with short oligosaccharide side chains, which are two or three residues long. MUC7 is synthesized in serous acinar and demilune cells of the (sero)mucous glands [Veerman et al., 1997b, 2003] and is detectable in all (sero)mucous glandular salivas [Bolscher et al., 1999]. In contrast to MUC5B, MUC7 binds a wide variety of bacterial species, including $S$. mutans [Liu et al., 2000]. Both mucins have been implicated in the protection against viruses [Bergey et al., 1993a, b; Bolscher et al., 2002].

The proline-rich glycoprotein, only present in parotid saliva, makes up about $15-20 \%$ of all parotid proteins. In unstimulated saliva it is a minor component that increases with increasing stimulation of the parotid glands to about $10 \%$ in stimulated whole saliva. This small cationic glycoprotein $\left(M_{\mathrm{r}} 36 \mathrm{kDa}\right)$ interacts particularly with Fusobacterium nucleatum and is involved in plaque formation [e.g. Kolenbrander and London, 1993]. 
Fig. 1. Main functions of saliva in relation to its constituents.

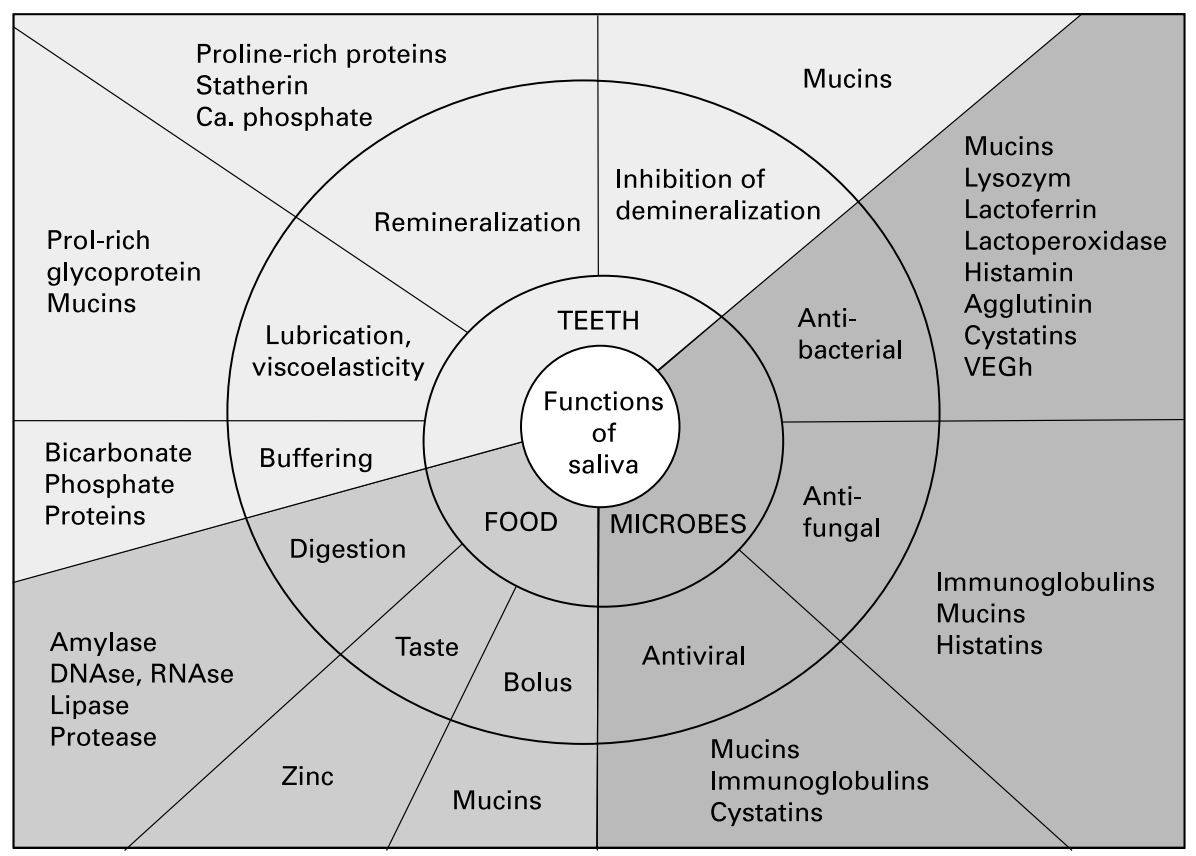

\section{Protective Properties of Minor Salivary Proteins}

Besides the major proteins described above, which account for approximately $50 \%$ of its total protein, saliva contains a number of antimicrobial proteins that are present in lower concentrations (table 1). A number of these are enzymes which even in low concentration can exert significant biological activity. Examples of antimicrobial proteins with enzymic activity are lactoperoxidase and lysozyme.

Lactoperoxidase catalyzes the oxidation of $\mathrm{SCN}^{-}$by hydrogen peroxide, resulting in the formation of $\mathrm{OSCN}^{-}$.

Lysozyme (muramidase) is another example of an antimicrobial enzyme. By hydrolyzing cell wall polysaccharides, it makes bacteria more vulnerable to lysis due to e.g. hypo-osmotic conditions in saliva, or other antimicrobial components. Strikingly, after heat inactivation, lysozyme still exhibits bactericidal activity, probably through its cationic character. This suggests a two-step working mechanism involving initial enzymatic cleavage of the cell wall, followed by killing of the bacterium due to physical-chemical perturbation of the cell membrane by lysozyme itself, or by other antibacterial systems. Studies on the cooperative action of salivary defense systems under physiological conditions are scarce, but it is conceivable that the concerted action of proteins having different mechanisms of action enhances the power of the oral defense.
Lactoferrin is an example of a nonenzymic antimicrobial protein. Its antimicrobial action is generally attributed to its iron-chelating property, which deprives microorganisms of this essential element. In addition, lactoferrin exhibits in vitro anti-inflammatory activities. Moreover, several domains are present within its polypeptide chain that exhibit antimicrobial activities. One of these is lactoferricin, an N-terminal peptide of 40 amino acid residues that is liberated upon combined pepsin and trypsin digestion. Lactoferricin is a cationic peptide which has a broadspectrum bactericidal activity [Groenink et al., 1999]. Another domain of lactoferrin has been implicated in the binding to salivary agglutinin, suggesting that both salivary proteins can act together [van der Kraan et al., 2004].

Salivary agglutinin was originally characterized as an $S$. mutans-agglutinating glycoprotein isolated from parotid saliva [Ericson and Rundegren, 1983; Lamont et al., 1991; Carlén and Olsson, 1995], but it is also present in submandibular and sublingual saliva [Ligtenberg et al., 2000; Bikker et al., 2002b]. It has now become clear that, besides $S$. mutans, a variety of other microbes are bound by agglutinin. The binding appears to be mediated by a relatively short peptide stretch, in the Scavenger Receptor Domains, which occur as tandemly repeating domains in agglutinin [Bikker et al., 2002a]. Besides being in saliva, agglutinin or closely related proteins have been detected in lung fluid, designated gp-340, and in brain, designated DMBT1 [Prakobphol et al., 2000; Ligtenberg et al., 2001]. 


\section{Protective Properties of Salivary Peptides}

In saliva at least three types of antimicrobial peptides can be distinguished: histatins, defensins and hCAP18/ LL37, a human cathelicidin. Of these antimicrobial salivary peptides the histatins have attracted the most attention over the last decades. These antimicrobial peptides have a broad antimicrobial activity not only against bacteria, but also against yeasts. Such peptides can be used as templates to develop a new generation of antibiotics, because they work very rapidly and efficiently, while they are negligibly cytotoxic [Helmerhorst et al., 1999; van 't Hof et al., 2001] and do not evoke resistance. Years before the discovery of the magainins, it was reported that histidine-rich proteins in human saliva had killing activity against Candida albicans and $S$. mutans [MacKay et al., 1984; Pollock et al., 1984]. Since then most of the research on histatins has focussed on their fungicidal activity [Helmerhorst et al., 1997, 1999, 2001; Edgerton et al., 2000; Gyurko et al., 2001; Ruissen et al., 2001, 2003; Faber et al., 2003]. The histatins are synthesized in the parotid and submandibular glands, meaning that under both stimulated and nonstimulated saliva flow conditions, histatins will be secreted into saliva. The fungicidal, and to a lesser extent the bactericidal activity, of histatins is sensitive to ionic strength, diminishing with increasing salt concentrations [Helmerhorst et al., 1997].

The salivary glands contribute relatively little to the defensin population in saliva, which mostly derives from epithelial cells and neutrophils [Mathews et al., 1999]. Particularly during oral inflammations the expression of e.g. $\beta$-defensin-2 is up-regulated [Abiko et al., 2002; Sawaki et al., 2002]. The same holds true for hCAP18/LL-37, derived from both neutrophils and the salivary glands [Murakami et al., 2002; Woo et al., 2003]. For hCAP18, the precursor of LL-37, no biological activity has been demonstrated thus far. Activation of hCAP18 results in the release of LL-37, consisting of the C-terminal 37 amino acids, which has broad-spectrum antimicrobial activity [Sörensen et al., 2001; den Hertog et al., 2004].

\section{Future Perspectives for Research}

Insight into the mechanism of action, in addition to knowledge of the structure-function relationship of antimicrobial proteins and peptides, makes it possible to design small, biologically active peptides that can be used as natural antimicrobials. In many cases it is not necessary to biosynthesize by recombinant techniques the whole polypeptide chain of biologically active proteins but instead only peptides encompassing the functional domain. This opens new perspectives for the application of peptides as instruments to fight multiresistant microorganisms, or as additives in mouthrinses, to restore functionality in patients in whom the natural protection is compromised.

\section{Potential Impact on Clinical Practice}

New formulations containing antimicrobial peptides derived from natural salivary components have been tested for their applicability in the treatment of oral inflammatory processes such as gingivitis and periodontitis. An example of a potential clinically applicable antimicrobial peptide is IB-367, a protegrin-derived synthetic peptide with in vitro and in vivo antimicrobial activity against the microflora associated with oral mucositis [Mosca et al., 2000]. Protegrin is the porcine analogue of human cathelicidin.

Another example is P113, an 11-amino acid fragment of histatin-3 [Rothstein et al., 2001]. Topical oral application of P113, or use of a mouthrinse containing P113, leads to significant reduction in experimental gingivitis [Paquette et al., 2002] without causing side effects. In addition, the nonhydrolyzable derivative $\mathrm{P} 113 \mathrm{D}$ retains its killing activity on Pseudomonas aeruginosa in the presence of sputum having increased electrolyte concentrations from cystic fibrosis patients [Sajjan et al., 2001]. 


\section{References}

Abiko Y, Jinbu Y, Noguchi T, Nishimura M, Kusano K, Amaratunga $\mathrm{P}$, Shibata T, Kaku T: Upregulation of human $\beta$-defensin 2 peptide expression in oral lichen planus, leukoplakia and candidiasis: An immunohistochemical study. Pathol Res Pract 2002;198:537-542.

Bergey EJ, Cho MI, Hammarskjold ML, Rekosh D, Levine MJ, Blumberg BM, Epstein LG: Aggregation of human-immunodeficiency-virus type- 1 by human salivary secretions. Crit Rev Oral Biol Med 1993a;4:467-474.

Bergey EJ, Gu M, Collins AR, Bradway SD, Levine MJ: Modulation of herpes-simplex virus type-1 replication by human salivary secretions. Ora Microbiol Immunol 1993b;8:89-93.

Bikker FJ, Ligtenberg AJM, Nazmi K, Veerman ECI, van 't Hof W, Bolscher JGM, Poustka A, Nieuw Amerongen AV, Mollenhauer J: Identification of the bacteria-binding peptide domain on salivary agglutinin (gp-340/DMBT1), a member of the scavenger receptor cysteinerich superfamily. J Biol Chem 2002a;277: 32109-32115.

Bikker FJ, Ligtenberg AJM, van der Wal JE, van den Keijbus PAM, Holskov U, Veerman ECI, Nieuw Amerongen AV: Immunohistochemical detection of salivary agglutinin/gp-340 in human parotid, submandibular, and labial salivary glands. J Dent Res 2002b;81;134-139.

Bobek LA, Tsai H, Biesbrock AR, Levine MJ: Molecular-cloning, sequence, and specificity of expression of the gene encoding the low-molecular-weight human salivary mucin (MUC7). J Biol Chem 1993;268:20563-20569.

Bolscher JGM, Groenink J, van der Kwaak JS, van den Keijbus PAM, van 't Hof W, Veerman ECI, Nieuw Amerongen AV: Detection and quantification of MUC7 in submandibular, sublingual, palatine, and labial saliva by antipeptide antiserum. J Dent Res 1999;78:13621369

Bolscher JGM, Nazmi K, Ran LJ, Van Engelenburg FAC, Schuitemaker H, Veerman ECI, Nieuw Amerongen AV: Inhibition of HIV-1 IIIB and clinical isolates by human parotid, submandibular, sublingual and palatine saliva. Eur J Oral Sci 2002;110:149-156.

Carlén A, Olsson J: Monoclonal antibodies against a high-molecular weight agglutinin block adherence to experimental pellicles on hydroxyapatite and aggregation of Streptococcus mutans. J Dent Res 1995;74:1040-1047.

Edgerton M, Koshlukova S, Araujo MWB, Patel RC, Dong J, Bruenn JA: Salivary histatin 5 and human neutrophil defensin 1 kill Candida albicans via shared pathways. Antimicrob Agents Chemother 2000;44:3310-3316.

Ericson T, Rundegren J: Characterization of a salivary agglutinin reacting with a serotype $\mathrm{c}$ strain of Streptococcus mutans. Eur J Biochem 1983; $133: 255-261$

Faber C, Stallmann HP, Lyaruu DM, De Blieck JMA, Bervoets TJM, Nieuw Amerongen AV, Wuisman PIJM: Release of antimicrobial peptide Dhvar-5 from polymethylmethacrylate beads. J Antimicrob Chemother 2003;51: 1359-1364.
Groenink J, Walgreen-Weterings E, van 't Hof W, Veerman ECI, Nieuw Amerongen AV: Cationic amphipathic peptides, derived from bovine and human lactoferrins, with antimicrobial activity against oral pathogens. FEMS Microbiol Lett 1999;179:217-222.

Gyurko C, Lendenmann U, Helmerhorst EJ, Troxler RF, Oppenheim FG: Killing of Candida albicans by histatin 5: Cellular uptake and energy requirement. Antonie Van Leeuwenhoek 2001;79:297-309.

Helmerhorst EJ, van 't Hof W, Breeuwer P, Veerman ECI, Abee T, Troxler RF, Nieuw Amerongen AV, Oppenheim FG: Characterization of histatin 5 with respect to amphipathicity, hydrophobicity, and effects on cell and mitochondrial membrane integrity excludes a candidacidal mechanism of pore formation. $\mathrm{J}$ Biol Chem 2001;276:5643-5649.

Helmerhorst EJ, van 't Hof W, Veerman ECI, Simoons-Smit AM, Nieuw Amerongen AV: Synthetic histatin analogs with broad-spectrum antimicrobial activity. Biochem J 1997;326: $39-45$.

Helmerhorst EJ, Reijnders IM, van 't Hof W, Veerman ECI, Nieuw Amerongen AV: A critical comparison of the hemolytic and fungicidal activities of cationic antimicrobial peptides against Candida albicans cells and human erythrocytes. FEBS Lett 1999;449:105-110.

den Hertog AL, Wong Fong Sang HW, Kraayenhof R, Bolscher JGM, van't Hof W, Veerman ECI, Nieuw Amerongen AV: Interactions of histatin 5 and histatin 5-derived peptides with liposome membranes: surface effects, translocation and permeabilization. Biochem J 2004, in press.

van 't Hof W, Veerman ECI, Helmerhorst EJ, Nieuw Amerongen AV: Antimicrobial peptides: Properties and applicability. Biol Chem 2001;382:597-619.

Kolenbrander PE, London J: Adhere today, here tomorrow: Oral bacterial adherence. J Bacteriol 1993; 175:3247-3252.

van der Kraan MIA, Groenink J, Nazmi K, Veerman ECI, Bolscher JGM, Nieuw Amerongen AV: Lactoferrampin: a novel antimicrobial peptide in the N1-domain of bovine lactoferrin. Peptides 2004, in press.

Lamont RJ, Demuth DR, Davis CA, Malamud D, Rosan B: Salivary-agglutinin-mediated adherence of Streptococcus mutans to early plaque bacteria. Infect Immun 1991;59:3446-3450.

Levine MJ, Reddy MS, Tabak LA, Loomis RE, Bergey EJ, Jones PC, Cohen RE, Stinson MW, Al-Hashimi I: Structural aspects of salivary glycoproteins. J Dent Res 1987;66:436-441.

Ligtenberg TJM, Bikker FJ, Groenink J, Tornoe I, Leth-Larsen R, Veerman ECI, Nieuw Amerongen AV, Holmskov U: Human salivary agglutinin binds to lung surfactant protein-D and is identical with scavenger receptor protein gp340. Biochem J 2001;359:243-248.

Ligtenberg AJM, Veerman ECI, Nieuw Amerongen AV: A role for Lewis a antigens on salivary agglutinin in binding to Streptococcus mutans. Antonie Van Leeuwenhoek 2000;77:21-30.
Liu B, Rayment SA, Gyurko C, Oppenheim FG, Offner GD, Troxler RF: The recombinant Nterminal region of human salivary mucin MG2 (MUC7) contains a binding domain for oral Streptococci and exhibits candidacidal activity. Biochem J 2000;345:557-564.

Loomis RE, Prakobphol A, Levine MJ, Reddy MS, Jones PC: Biochemical and biophysical comparison of two mucins from human submandibular-sublingual saliva. Arch Biochem Biophys 1987;258:452-464.

MacKay BJ, Denepitiya L, Iacono VJ, Krost SB, Pollock JJ: Growth-inhibitory and bactericidal effects of human parotid salivary histidine-rich polypeptides on Streptococcus mutans. Infect Immun 1984;44:695-701.

Mathews M, Jia HP, Guthmiller JM, Losh G, Graham S, Johnson GK, Tack BF, McCray PB: Production of $\beta$-defensin antimicrobial peptides by the oral mucosa and salivary glands. Infect Immun 1999;67:2740-2745.

Mosca DA, Hurst MA, So W, Viajar BSC, Fujii CA, Falla TJ: IB-367, a protegrin peptide with in vitro and in vivo activities against the microflora associated with oral mucositis. Antimicrob Agents Chemother 2000;44:1803-1808.

Murakami M, Ohtake T, Dorschner RA, Gallo RL: Cathelicidin antimicrobial peptides are expressed in salivary glands and saliva. J Dent Res 2002;81:845-850.

Nieuw Amerongen AV, Bolscher JGM, Veerman ECI: Salivary mucins: Protective functions in relation to their diversity. Glycobiology 1995 ; 5:733-740.

Nieuw Amerongen AV, Oderkerk CH, Driessen AA: Role of mucins from human whole saliva in the protection of tooth enamel against demineralizatiuon in vitro. Caries Res 1987;21:297309.

Nieuw Amerongen AV, Veerman ECI: Saliva - the defender of the oral cavity. Oral Dis 2002;8: 12-22.

Paquette DW, Simpson DM, Friden P, Braman V, Williams RC: Safety and clinical effects of topical histatin gels in humans with experimental gingivitis. J Clin Periodontol 2002;29:10511058 .

Pollock JJ, Denepitiya L, MacKay BJ, Iacono V: Fungistatic and fungicidal activity of human parotid salivary histidine-rich polypeptides on Candida albicans. Infect Immun 1984:44:702707.

Prakobphol A, Xu F, Hoang VM, Larsson T, Bergstrom J, Johansson I, Frangsmyr L, Holmskov U, Leffler H, Nilsson C, Boren T, Wright JR, Stromberg N, Fisher SJ: Salivary agglutinin, which binds Streptococcus mutans and Helicobacter pylori, is the lung scavenger receptor cysteine-rich protein gp-340. J Biol Chem 2000; 275:39860-39866.

van der Reijden WA, Veerman ECI, Nieuw Amerongen AV: Shear rate dependent viscoelastic behavior of human glandular salivas. Biorheology 1993;30:141-152. 
Rothstein DM, Spacciapoli P, Tran LT, Xu T, Roberts FD, Dalla Serra M, Buxton DK, Oppenheim FG, Friden P: Anticandida activity is retained in P-113, a 12-amino acid fragment of histatin 5. Antimicrob Agents Chemother 2001;45:1367-1373

Rudney JD, Hickey KL, Ji Z: Cumulative correlations of lysozyme, lactoferrin, peroxidase, SIgA, amylase, and total protein concentrations with adherence of oral viridans streptococci to microplates coated with human saliva. J Dent Res 1999;78:759-768.

Ruissen ALA, Groenink J, Helmerhorst EJ, Walgreen-Weterings $\mathrm{E}$, van 't Hof $\mathrm{W}$, Veerman ECI, Nieuw Amerongen AV: Effects of histatin 5 and derived peptides on Candida albicans. Biochem J 2001;356:361-368.

Ruissen ALA, Groenink J, Krijtenberg P, Walgreen-Weterings $\mathrm{E}$, van 't Hof $\mathrm{W}$, Veerman ECI, Nieuw Amerongen AV: Internalisation and degradation of histatin 5 by Candida albicans. Biol Chem 2003;384:183-190.
Sajjan US, Tran LT, Sole N, Rovaldi C, Akiyama A, Friden PM, Forstner JF, Rothstein DM: P$113 \mathrm{D}$, an antimicrobial peptide active against Pseudomonas aeruginosa, retains activity in the presence of sputum from cystic fibrosis patients. Antimicrob Agents Chemother 2001; 45:3437-3444.

Sawaki K, Mizukawa N, Yamaai T, Fukunaga J, Sugahara T: Immunohistochemical study on expression of $\alpha$-defensin and $\beta$-defensin- 2 in human buccal epithelia with candidiasis. Oral Dis 2002;8:37-41.

Sörensen OE, Follin P, Johnson AH, Calafat J, Tjabringa GS, Hiemstra PS, Borregaard N: Human cathelicidin, hCAP18, is processed to the antimicrobial peptide LL37 by extracellular cleavage with proteinase 3. Blood 2001;97: 3951-3959.

Thornton DJ, Khan N, Mehrotra R, Howard M, Veerman E, Packer NH, Sheehan JK: Salivary mucin MG1 is comprised almost entirely of different glycosylated forms of the MUC5B gene product. Glycobiology 1999;9:293-302.

Veerman ECI, Bank CMC, Namavar F, Appelmelk BJ, Bolscher JGM, Nieuw Amerongen AV: Sulfated glycans on oral mucin as receptors for Helicobacter pylori. Glycobiology 1997a;7: 737-743.
Veerman ECI, Bolscher JGM, Appelmelk BJ, Bloemena E, van den Berg TK, Nieuw Amerongen AV: A monoclonal antibody directed against high $\mathrm{M}_{\mathrm{r}}$ salivary mucins recognizes the $\mathrm{SO}_{3^{-}}$ 3GalB1-3GlcNAc moiety of sulfo-Lewis ${ }^{\mathrm{a}}$ : A histochemical survey of human and rat tissue. Glycobiology 1997b;7:37-43.

Veerman ECI, van den Keijbus PAM, Nazmi K, Vos W, van der Wal JE, Bloemena E, Bolscher JGM, Nieuw Amerongen AV: Distinct localization of MUC5B glycoforms in the human salivary glands. Glycobiology 2003;13:363366.

Veerman ECI, Ligtenberg AJM, Schenkels LCPM, Walgreen-Weterings $E$, Nieuw Amerongen AV: Binding of human high-molecular-weight salivary mucins (MG1) to Hemophilus parainfluenzae. J Dent Res 1995;74:351-357.

Woo JS, Jeong JY, Hwang YJ, Chae SW, Hwang SJ, Lee HM: Expression of cathelicidin in human salivary glands. Arch Otolaryngol Head Neck Surg 2003;129:211-214. 